\title{
Low-Temperature Adsorption Study of Carbon Dioxide on Porous Magnetite Nanospheres Iron Oxide
}

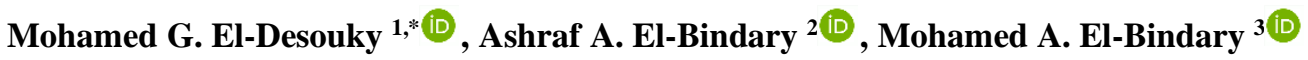 \\ Egyptian Propylene and Polypropylene Company, Port Said 42511, Egypt \\ Chemistry Department, Faculty of Science, Damietta University, Damietta 34517, Egypt \\ Basic Science Department, Higher Institute of Engineering and Technology, Damietta, Egypt \\ Correspondence: ch.moh.gamal@gmail.com;
}

Scopus Author ID 57194898913

Received: 7.07.2021; Revised: 19.09.2021; Accepted: 22.09.2021; Published: 8.11.2021

\begin{abstract}
Porous magnetite $\mathrm{Fe}_{3} \mathrm{O}_{4}$ nano-spheres (PMNs) have been successfully produced and have been demonstrated to be high-efficiency adsorbents. The PMNs have a spherical shape with an average particle size of $25.84 \mathrm{~nm}$. The BET surface area of PMNs is $143.65 \mathrm{~m}^{2} \mathrm{~g}^{-1}$, with a total pore volume of $0.16 \mathrm{~cm}^{3} \mathrm{~g}^{-1}$. As a result of $\mathrm{CO} 2$ adsorption and desorption features on dry PMNs, this synthesized material is projected to be exploited as possible $\mathrm{CO}_{2}$ sequestration reservoirs to minimize greenhouse gas emissions. $\mathrm{CO}_{2}$ adsorption was best at low temperatures and with dry PMNs. PMNs, on the other hand, has a very high adsorption capacity of $0.96 \mathrm{mmol} / \mathrm{g}$. According to the IUPAC categorization of adsorption isotherms, all $\mathrm{CO}_{2}$ adsorption isotherms of coal samples fall into type $\mathrm{I}$, which most likely indicates adsorption restricted to a few layers of molecules (micropores and mesopores). Langmuir, Henry, Dubbin, Temkin, Toth, Harkin-Jura, Elovich, Redlich Peterson, and Josene models suit any experimental adsorption data that best predict the heterogeneous surface features of PMNs.
\end{abstract}

Keywords: PMNs; isotherm models; $\mathrm{CO}_{2}$ adsorption.

(C) 2021 by the authors. This article is an open-access article distributed under the terms and conditions of the Creative

Commons Attribution (CC BY) license (https://creativecommons.org/licenses/by/4.0/).

\section{Introduction}

Global warming is primarily caused by the release of carbon dioxide $(\mathrm{CO} 2)$ into the atmosphere. $\mathrm{CO}_{2}$ is a primary greenhouse gas produced by the electricity, gas, and refinery industries, as well as the chemical and petrochemical, iron and steel, and cement industries. While $\mathrm{CO}_{2}$ levels rose from 315 parts per million in March 1958 to 398 parts per million in January 2014, the global average temperature rose by 0.6 to 1 degree Celsius [1-4], according to the Scripps Institute of Oceanography. By 2100, average $\mathrm{CO}_{2}$ concentrations might climb to 570 parts per million, resulting in global average temperature and mean sea level rises of 1.9 degrees Celsius and 3.8 meters, respectively, according to the International Panel on Climate Change (IPCC) [5].

Because the surface area is intimately linked to performance in many applications, it is one of the most important characteristics of porous materials. A few examples include gas storage, separation, and catalysis. Brunauer-Emmett-Teller (BET) analysis based on nitrogen or argon adsorption isotherms is the most common method for determining porous materials' surface area and pore volume, including microporous and mesoporous materials. The porous metal oxide, which contains pores dictated by the crystal structure, continues to draw much interest, as indicated by the enormous number of evaluations it receives. As sorbent materials, this is especially true with mesoporous metal oxide. Organic metal frameworks produced 
mesoporous metal oxide. MOFs have a variety of characteristics that make them a significant part of the sorbent exploration process. Pores in MOFs are particularly interesting since they become an integral component of the material's crystal structure and exhibit a degree of homogeneity not seen in other sorbents[6,7].

Understanding $\mathrm{CO}_{2}$ adsorption on PMNs during sequestration, as well as the mechanism for $\mathrm{CO}_{2}$ desorption from PMNs via depressurization, is crucial. The difference between hysteresis and adsorption and isothermic desorption of gases on porous materials is known as adsorption and isothermic desorption of gases on porous materials[8,9]. Adsorption and isothermic desorption of gases on mesoporous materials are the deviations that occur between hysteresis [10,11]. $\mathrm{CO}_{2}$ sorption hysteresis is favorable for long-term $\mathrm{CO} 2$ sequestration. Several $\mathrm{CO}_{2}$ sorption research studies on various coal specimens are currently underway, not only to provide a realistic estimate of PMNs bed gas capacity, but also to better grasp the fundamental Gas Adsorption and Desorption Mechanisms[12,13].

This research looked into $\mathrm{CO}_{2}$ adsorption and desorption on dry PMNs in subcritical conditions. The experiment was conducted at $273 \mathrm{~K}$ with a $\mathrm{CO}_{2}$ adsorption isotherm and 1 bar of pressure. Meanwhile, by lowering $\mathrm{CO}_{2}$ pressure to 1 bar, desorption has been achieved. Finally, to match the equilibrium adsorption data, isotherm adsorption models were used[14,15].

\section{Materials and Methods}

\subsection{Adsorbent.}

The adsorbent was produced and characterized as previously described[16], and the experimental approach was previously described[11].

\section{Results and Discussion}

When the temperature was raised to $273 \mathrm{~K}$, the amount of adsorbed $\mathrm{CO}_{2}$ on PMNs increased. The experimental values of adsorbed $\mathrm{CO}_{2}$ on PMNs at $273 \mathrm{~K}$ are depicted in Figure 1. $273 \mathrm{~K}$ is the total quantity of $\mathrm{CO}_{2}$ adsorbed on the PMNs in the sample. There is a lot of adsorption on the surface of the PMNs because the sample is heterogeneous and has a small specific surface area $\left(143.65 \mathrm{~m}^{2} / \mathrm{g}\right)$. According to the IUPAC classification, all $\mathrm{CO}_{2}$ adsorption on PMNs follows type IV, which represents mono-multilayer adsorption, hysteresis loop Type III; at high pressure, the slope shows increased adsorbate uptake as the pores fill, with the inflection point typically occurring near the completion of the first monolayer and capillary condensation that occurs in mesoporous materials. Isothermic adsorption isotherms are higher than desorption isotherms in reality. The desorption isotherm at $273 \mathrm{~K}$ was calculated from the experience of depressurization after adsorption ended, and the total amount of $\mathrm{CO}_{2}$ adsorbed in the gas phase was more than the adsorption isotherm. Figure 1 shows hysteresis in the $\mathrm{CO}_{2}$ adsorption and PMNs desorption curves. $\mathrm{CO}_{2}$ absorption and evaporation In isotherm studies, all PMNs samples demonstrate positive hysteresis between isothermic adsorption and desorption. 


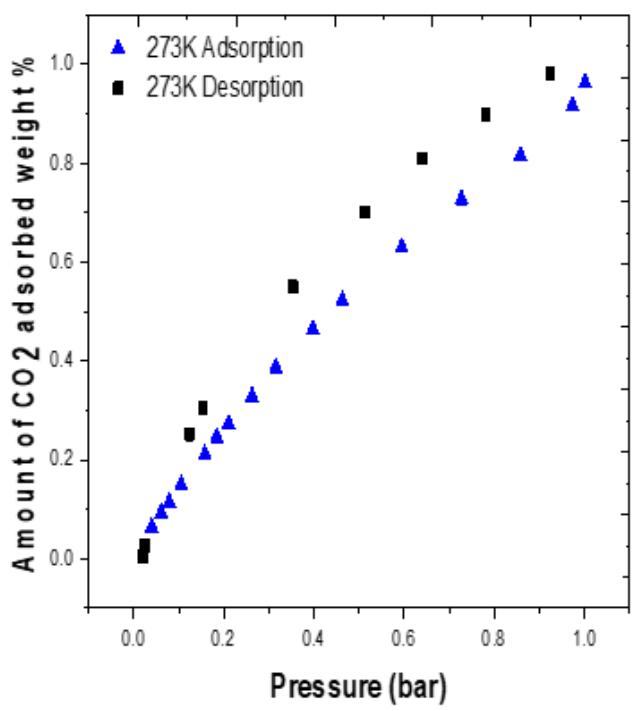

Figure 1. $\mathrm{CO}_{2}$ adsorption and desorption on PMNs were investigated at $273.15 \mathrm{~K}$.

\subsection{Adsorption isotherms.}

Theoretical models of isothermic adsorption describe adsorption behavior in great detail. These models explain how the adsorbent interacts with the adsorbent, as well as the interaction's existence and mechanism. They elucidate how the adsorbent interacts with the adsorbent, as well as the role of the adsorbent in the existence and process of gas adsorption[18]. Equilibrium isotherm data generated by models with two or three parameters can be used to learn about adsorption mechanisms, surface properties, and adsorbent affinity. As a result, ensuring that the experimental equilibrium curves are accurately correlated is crucial for optimizing the parameters for designing adsorption systems. Langmuir, Henry, Dubbin, Temkin, Toth, Herkin-Jurra, Elovich, Redlich Beterson, and Josene models were employed to study adsorption behavior [20].

\subsubsection{Henry's isotherms.}

The volume of the surface adsorbent is proportional to the partial pressure of the adsorptive gas in this isothermic adsorption method. At low concentrations, this isothermic model fits well, ensuring that all adsorbed molecules are segregated from their neighbors[22,23]. The balance adsorbs concentrations in the liquid, and adsorbed phases are coupled in this method by a linear expression:

$$
\mathrm{q}_{\mathrm{e}}=\mathrm{K}_{\mathrm{HE}} \mathrm{P}_{\mathrm{e}}
$$

where qe represents the amount of adsorbate at equilibrium (mmol/g), $\mathrm{K}_{\mathrm{HE}}$ represents Henry's adsorption constant, and $\mathrm{P}_{\mathrm{e}}$ represents the adsorbate on the adsorbent equilibrium gas pressure.

\subsubsection{Langmuir isotherms.}

Langmuir adsorption was first devised to explain adsorption in the gas-solid phase and is now used to assess and quantify the adsorption capacities of various adsorbents[24]. By balancing relative adsorption and desorption rates, the Langmuir isotherm accounts for surface coverage (dynamic equilibrium). 


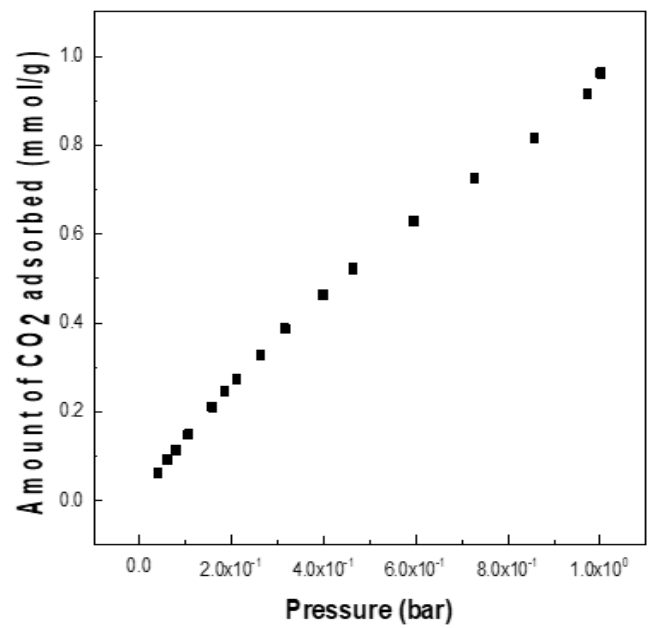

Figure 2. Isotherms by Henry (linearized plots of $\mathrm{CO}_{2}$ sorption isotherms).

Adsorption is proportional to the amount of exposed adsorbent surface, while desorption is related to the amount of closed adsorbent surface[25]. In linear form, the Langmuir equation is:

$$
\mathrm{p}_{\mathrm{e}} / \mathrm{q}_{\mathrm{e}}=1 /\left(\mathrm{q}_{\mathrm{m}} \mathrm{K}_{\mathrm{L}}\right)+\mathrm{p}_{\mathrm{e}} / \mathrm{q}_{\mathrm{m}}
$$

where the pressure of the gas and the pressure of the air are equal (bar). $\mathrm{K}_{\mathrm{L}}$ is a Langmuir constant related to adsorption capacity $(\mathrm{mmol} / \mathrm{g})$ that can be linked to changes in the adsorbent's correct area and porosity, meaning that a greater surface area and pore volume will result in increased adsorption efficiency[28].

$$
\mathrm{R}_{\mathrm{L}}=1 /\left(1+\mathrm{P}_{0} \mathrm{~K}_{\mathrm{L}}\right)
$$

The Langmuir constant ( $\mathrm{mol} / \mathrm{g}$ ) is $\mathrm{K}_{\mathrm{L}}$, while the starting pressure of the gas is $\mathrm{P}_{\mathrm{O}}$ (bar). When $R_{L}$ values are negative, the adsorption is unfavourable. $R_{L}>1$, linear when $R_{L}=1$, favourable when $0<R_{L}<1$, and irreversible when $R_{L}=0$ (Figure 3).

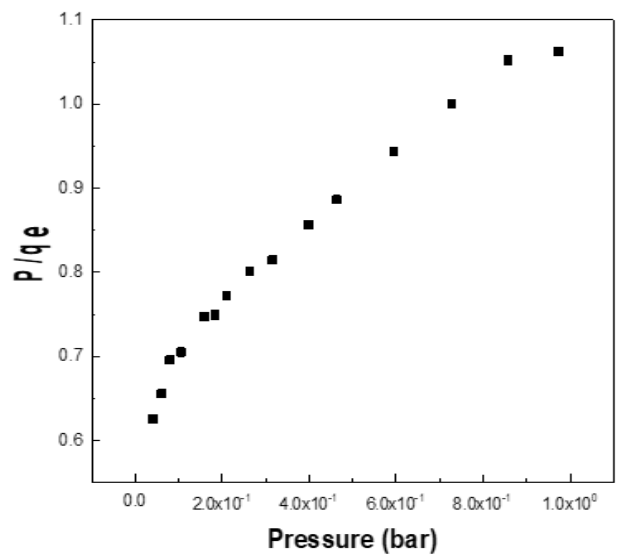

Figure 3. Linear plots of $\mathrm{CO}_{2}$ sorption isotherms (Langmuir isotherm).

\subsubsection{Freundlich Isotherms.}

For adsorption on heterogonous surfaces, the isotherm holds[29]. The surface heterogeneity, as well as the exponential distribution of active sites and energy, are all expressed by this isotherm. [30]. Figure 4 The Freundlich isotherm has a linear version[29,31] as follows:

$$
\log \mathrm{q}_{\mathrm{e}}=\log \mathrm{K}_{\mathrm{F}}+1 / \mathrm{n} \log \mathrm{P}_{\mathrm{e}}
$$

where $\mathrm{K}_{\mathrm{F}}$ stands for adsorption capacity ( $\mathrm{mmol} / \mathrm{g}$ ) and $1 / \mathrm{n}$ stands for adsorption intensity; it also stands for energy distribution and adsorbate site heterogeneity. 


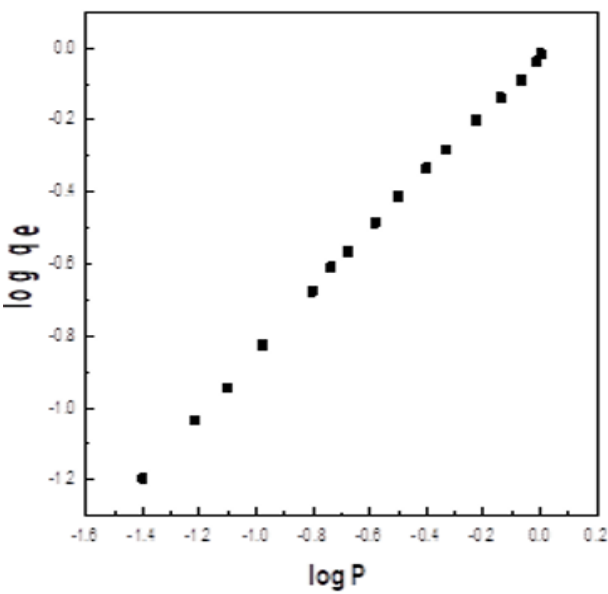

Figure 4. Linear plots of $\mathrm{CO}_{2}$ sorption isotherms (Freundlich isotherm).

\subsubsection{Dubinin-Radushkevich isotherm.}

The Dubinin-Radushkevich isotherm model[32] is a popular empirical adsorption model for describing adsorption mechanisms on heterogeneous surfaces with a Gaussian energy distribution [33,34]. This isotherm is only useful for intermediate concentrations of adsorbents since it has implausible asymptotic behavior and does not anticipate Henry's equations at low pressure [35]. In the model, which is a semi-empirical equation, pore-filling is accompanied by adsorption. It is a fundamental equation that quantitatively characterizes the adsorption of microporous sorbents by gases and vapors and assumes a multilayer character involving the Van Der Waal forces, and it is applicable to physical adsorption processes[13,36].

The physical and chemical adsorption of metal ions is usually distinguished. Because the Dubinin-Radushkevich isotherm is temperature-dependent, all relevant data may be acquired by graphing adsorption data as a function of the adsorbed sum logarithm versus the square of potential energy at different temperatures[37].

$$
\operatorname{Ln} \mathrm{q}_{\mathrm{e}}=\ln \mathrm{Q}_{\mathrm{DR}}-\mathrm{K}_{\mathrm{DR}} \varepsilon^{2}
$$

$$
\varepsilon=\operatorname{RT}\left(1+1 / \mathrm{P}_{\mathrm{e}}\right)
$$

where $\mathrm{K}_{\mathrm{DR}}$ is the Dubinin-Radushkevich constant and is the Polanyi potential, $\mathrm{T}$ denotes absolute temperature, and $\mathrm{R}$ denotes the gas constant $\left(8.314 \mathrm{Jmol}^{-1} \mathrm{k}^{-1}\right.$ ) (Figure 5)

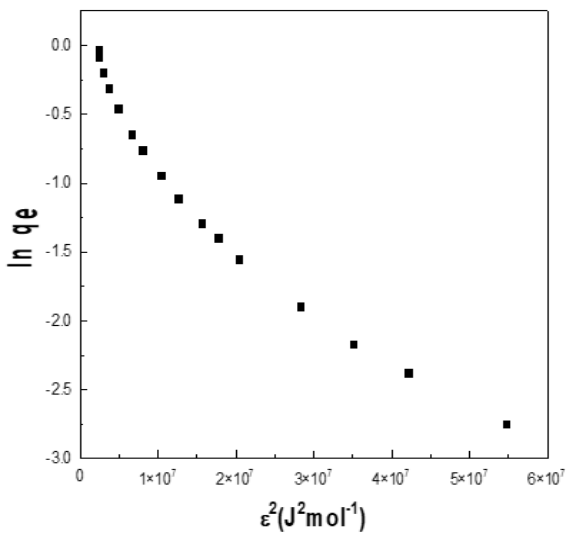

Figure 5. Linear graphs of CO2 sorption isotherms (Dubinin-Radushkevich Isotherm).

\subsubsection{Harkin-Jura Isotherm.}

The Harkin-Jura isotherm model assumes multilayer adsorption on absorbent surfaces with heterogeneous pore distribution (Figure 6). This model is expressed in the following way: 


$$
\frac{1}{\mathrm{q}_{\mathrm{e}}^{2}}=\frac{\mathrm{B}}{\mathrm{A}}-\frac{1}{\mathrm{~A}} \log \mathrm{P}_{\mathrm{e}}
$$

where B and A are Harkin-Jura constants found by graphing $1 / \mathrm{q}^{2}$ against $\log \mathrm{P}_{\mathrm{e}}$ [38].

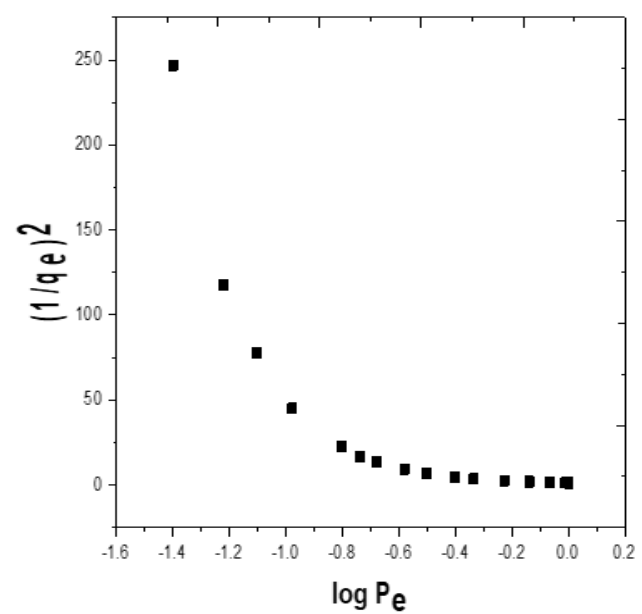

Figure 6. Linear plots of $\mathrm{CO}_{2}$ sorption isotherms (Harkin-Jura isotherm).

\subsubsection{Temkin isotherm.}

The Temkin isotherm model accounts for the impact of indirect adsorbing desorbing interactions on the adsorption process, as well as the assumption that as surface coverage rises, the adsorption heat $\left(\mathrm{H}_{\mathrm{ads}}\right)$ of all layer molecules reduces linearly [39] (Figure 7). The Temkin isotherm is only valid for intermediate ion concentration ranges [40]. The linear form of the Temkin isotherm model is as follows:

$$
\mathrm{q}_{\mathrm{e}}=\beta_{\mathrm{T}} \ln \mathrm{K}_{\mathrm{T}}+\beta_{\mathrm{T}} \ln \mathrm{P}_{\mathrm{e}}
$$

Plotting the parameters and $\mathrm{K}_{\mathrm{T}}$ yields the Temkin constants.

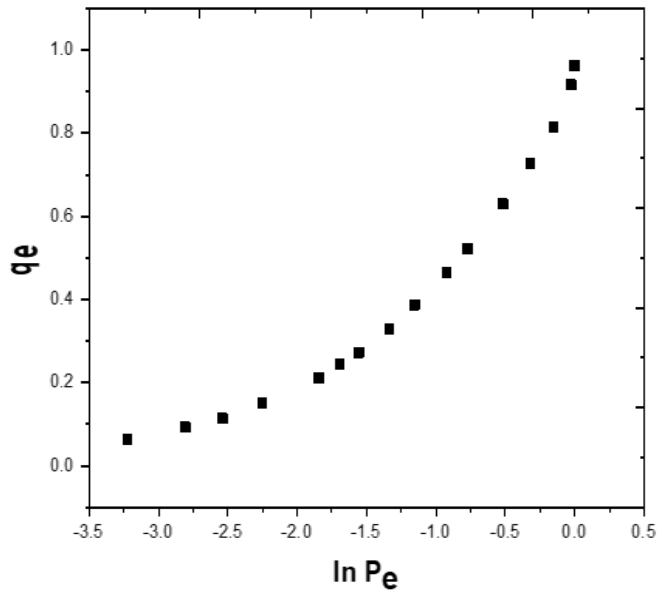

Figure 7. Linear plots of $\mathrm{CO}_{2}$ sorption isotherms (Temkin isotherm).

\subsubsection{Elovich isotherm}

The kinetic principle implies that adsorption sites expand exponentially with adsorption, implying multilayer adsorption[41]. This model's equation is based on this concept. The equation was originally designed to describe the kinetics of gas chemisorption on solids[42,43].

The linear versions of the Elovich model are as follows[44]: 


$$
\frac{\mathrm{q}_{\mathrm{e}}}{\mathrm{q}_{\mathrm{m}}}=\mathrm{K}_{\mathrm{E}} \mathrm{P}_{\mathrm{e}} \exp \frac{\mathrm{q}_{\mathrm{e}}}{\mathrm{q}_{\mathrm{m}}}
$$

The linear form, on the other hand, is as follows:

$$
\ln \frac{\mathrm{q}_{\mathrm{e}}}{\mathrm{P}_{\mathrm{e}}}=\ln \mathrm{K}_{\mathrm{e}} \mathrm{q}_{\mathrm{m}^{-}} \frac{\mathrm{q}_{\mathrm{e}}}{\mathrm{q}_{\mathrm{m}}}
$$

Elovich maximal adsorption capacity and Elovich constant may be calculated using the slope and intercept of the $\ln \left(\mathrm{qe} / \mathrm{P}_{\mathrm{e}}\right) v s$. $\mathrm{q}_{\mathrm{e}}$ plot (Figure 8).

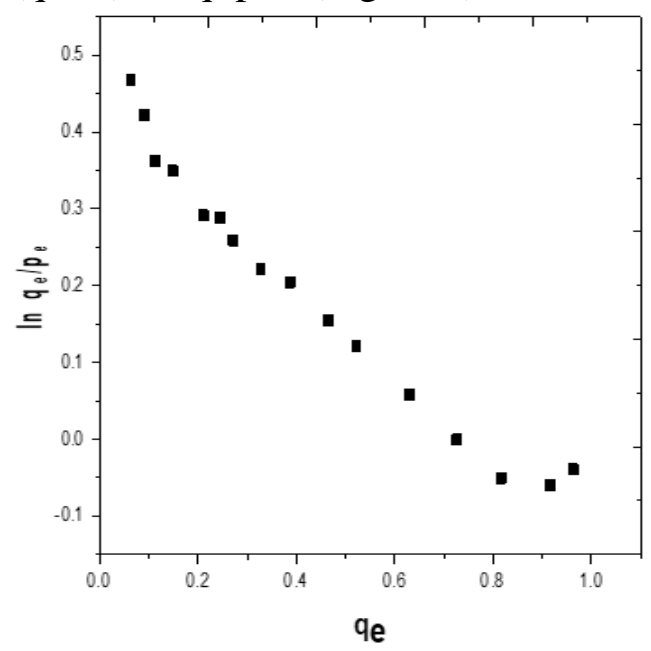

Figure 8. Linear graphs of $\mathrm{CO}_{2}$ sorption isotherms (Elovich isotherm).

\subsubsection{Redlich-Peterson Isotherm.}

The Langmuir and Freundlich isotherms are combined in the Redlich-Peterson isotherm. The numerator is derived from the isothermic Langmuir equation, which benefits from approaching the Henry zone at infinite dilution[45]. This isothermic model is an empirical isotherm with three parameters. It combines elements of the Langmuir and Freundlich equations, resulting in a mixed adsorption mechanism that differs from ideal monolayer adsorption. [44]. This model is defined by the following expression:

$$
\mathrm{q}_{\mathrm{e}}=\frac{\mathrm{AP}_{\mathrm{e}}}{1+\mathrm{BP}_{\mathrm{e}}^{\beta}}
$$

Where $\mathrm{A}$ is the Redich-Peterson isotherm constant, $\mathrm{B}$ is the constant, qe is the equilibrium adsorbate loading on the adsorbent ( $\mathrm{mmol} / \mathrm{g}$ ), Pe is the equilibrium pressure (bar), and is a variable between 0 and 1 . At large adsorbate gas-phase concentrations, the Freundlich equation is reduced:

$$
\mathrm{q}_{\mathrm{e}}=\frac{\mathrm{A}}{\mathrm{B}} \mathrm{P}_{\mathrm{e}}^{1-\beta}
$$

where $A / B=K F$ and $(1-\beta)=1 / n$ of the Freundlich isotherm model. when $\beta=1$, (8) reduces to Langmuir equation with $b=B$ (Langmuir adsorption constant ( $\mathrm{mmol} / \mathrm{g}$ ) which is related to the energy of adsorption. 
$A=b q m$ where $q m l$ is Langmuir maximum adsorption capacity of the adsorbent (mmol/g); when $\beta=0$, (8) reduces to Henry's equation with $1 /(1+b)$ representing Henry's constant.

The linear form of the Redlich-Peterson isotherm can be expressed as follows:

$$
\ln \frac{\mathrm{P}_{\mathrm{e}}}{\mathrm{q}_{\mathrm{e}}}=\beta \ln \mathrm{P}_{\mathrm{e}}-\ln \mathrm{A}
$$

The Redlich-Peterson constants can be determined by plotting $\ln (\mathrm{Pe} / \mathrm{qe})$ vs. In $\mathrm{Pe}$, where is the slope and $\mathrm{A}$ is the intercept (Figure. 9). This isotherm model has a linear dependence on concentration in the numerator and an exponential function in the denomination, which reflect adsorption equilibrium over a wide range of adsorbate concentrations because of its adaptability. It works in both homogeneous and heterogeneous environments [46].

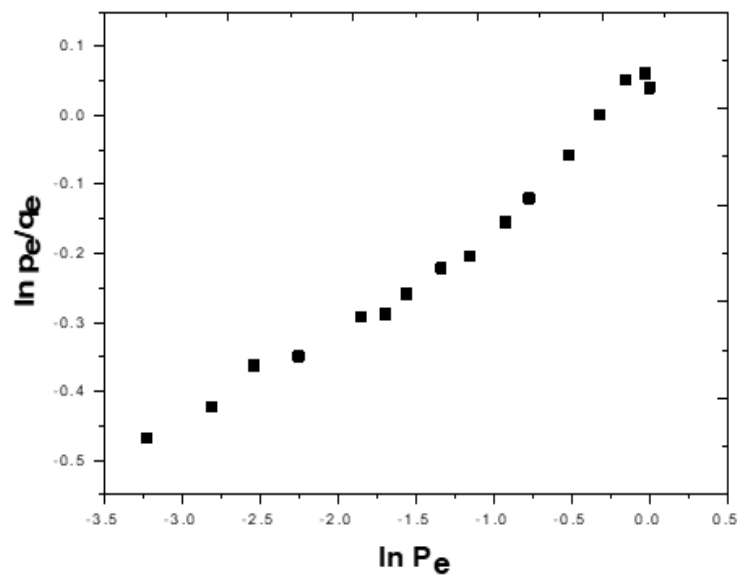

Figure 9. Linear graphs of $\mathrm{CO}_{2}$ sorption isotherms (Redlich-Peterson isotherm).

\subsubsection{Toth isotherm.}

The Toth isotherm is an empirical variant of the Langmuir equation designed to minimize the difference between experimental and expected equilibrium data values. This model excels at simulating heterogeneous adsorption systems that satisfy both the low and high ends of the adsorbate concentration spectrum[47]. This is how the Toth isotherm model is written:

$$
\frac{\mathrm{q}_{\mathrm{e}}}{\mathrm{q}_{\mathrm{m}}}=\frac{\mathrm{K}_{\mathrm{e}} \mathrm{P}_{\mathrm{e}}}{\left[1+\left(\mathrm{K}_{\mathrm{L}}+\mathrm{P}_{\mathrm{e}}\right)^{\mathrm{n}}\right]^{1 / \mathrm{n}}}
$$

$\mathrm{K}_{\mathrm{L}}$ is the Toth isotherm constant in $(\mathrm{mmol} / \mathrm{g})$, and $\mathrm{n}$ is the Toth isotherm constant in $(\mathrm{mmol} / \mathrm{g})$. When $\mathrm{n}=1$, this equation reduces to the Langmuir isotherm equation. As a result, the parameter $\mathrm{n}$ measures the heterogeneity of the adsorption system, and if it deviates from unity (1), the system is considered heterogeneous. $\mathrm{T}_{\mathrm{o}}$ obtain a linear form, the Toth isotherm can be rearranged as follows:

$$
\ln \frac{\mathrm{q}_{\mathrm{e}}{ }^{\mathrm{n}}}{\mathrm{q}_{\mathrm{m}}{ }^{\mathrm{n}}-\mathrm{q}_{\mathrm{e}}{ }^{\mathrm{n}}}=\mathrm{n} \ln \mathrm{K}_{\mathrm{L}}+\mathrm{n} \ln \mathrm{P}_{\mathrm{e}}
$$


Using the origin software, the nonlinear curve fitting approach can be utilized to evaluate the values of the Toth model parameters. When compared to the Freundlich model, this isothermic model was utilized to simulate multiple multilayers and heterogeneous adsorption systems, indicating that PMNs have a heterogeneous surface (Figure 10).

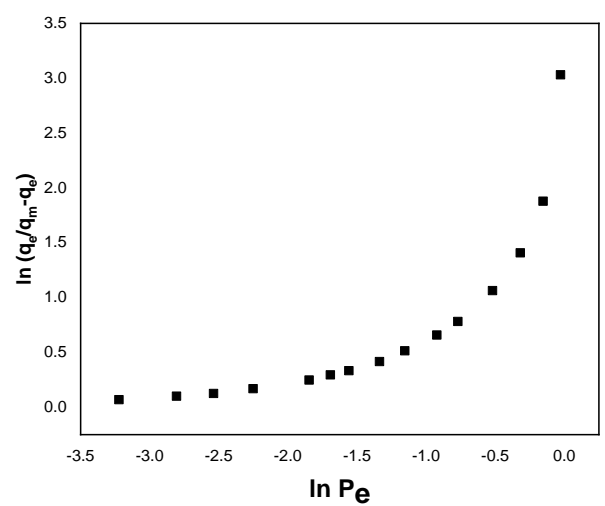

Figure 10. Linear plots of $\mathrm{CO}_{2}$ sorption isotherms (Toth isotherm).

\subsubsection{Josen isotherm.}

A simple equation based on the energy distribution of adsorbate-adsorbent interactions sites is used in adsorption. [48] This is predicted by the Jossens isotherm model. This concept suggests that the adsorbent has a heterogeneous surface in terms of interactions with it. The following is how the Jossen isotherm is expressed:

$$
\mathrm{P}_{\mathrm{e}}=\frac{\mathrm{q}_{\mathrm{e}}}{\mathrm{H}} \exp \mathrm{Fq}_{\mathrm{e}}^{\mathrm{p}}
$$

where $\mathrm{H}$ is the Jossens isotherm constant (also known as Henry's constant), $\mathrm{p}$ is the Jossens isotherm constant (which remains constant independent of temperature or adsorbent type), and F is the Jossens isotherm constant (also known as Henry's constant) (Figure 11).

The equation becomes Henry's law when capacity is low. Rearranging the furniture, however (17),

$$
\ln \frac{\mathrm{P}_{\mathrm{e}}}{\mathrm{q}_{\mathrm{e}}}=-\ln \mathrm{H}+\mathrm{F} \mathrm{q}_{\mathrm{e}}^{\mathrm{p}}
$$

The values of $\mathrm{H}$ and $\mathrm{F}$ can be calculated using a plot of $\ln \left(\mathrm{P}_{\mathrm{e}} / \mathrm{q}_{\mathrm{e}}\right)$ vs $\mathrm{q}_{\mathrm{e}}$ using a least square fitting method.

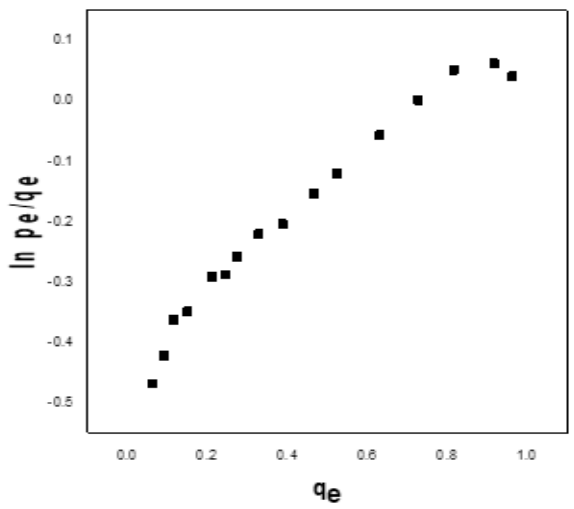

Figure 11. Linear plots of $\mathrm{CO}_{2}$ sorption isotherms (Josenes isotherm). 
Table 1. Isotherms and their linear forms for the adsorption of $\mathrm{CO}_{2}$ onto PMNs.

\begin{tabular}{|c|c|c|}
\hline Isotherm & Value of param & ters \\
\hline \multirow{4}{*}{ Henry } & $\mathrm{q}_{\mathrm{m} \exp }(\mathrm{mmol} / \mathrm{g})$ & 0.96 \\
\hline & $\mathrm{q}_{\mathrm{m}}(\mathrm{mmol} / \mathrm{g})$ & 0.92 \\
\hline & $\mathrm{K}_{\mathrm{HE}}$ & 0.9105 \\
\hline & $\mathrm{R}^{2}$ & 0.9916 \\
\hline \multirow{4}{*}{ Langmnir } & $\mathrm{q}_{\mathrm{m}}(\mathrm{mmol} / \mathrm{g})$ & 0.94 \\
\hline & $\mathrm{K}_{\mathrm{L}}\left(\mathrm{bar}^{-1}\right)$ & 0.652 \\
\hline & $\mathrm{R}_{\mathrm{L}}$ & 0.9 \\
\hline & $\mathrm{R}^{2}$ & 0.971 \\
\hline \multirow{3}{*}{ Freundlich } & $\mathrm{K}_{\mathrm{F}}$ & 0.15 \\
\hline & $1 / \mathrm{n}$ & 0.833 \\
\hline & $\mathrm{R}^{2}$ & 0.99871 \\
\hline \multirow{3}{*}{$\begin{array}{l}\text { Dubinin-- } \\
\text { Radushkevich }\end{array}$} & $\mathrm{QDR}_{\mathrm{DR}}$ & 0.248 \\
\hline & $\mathrm{K}_{\mathrm{DR}}$ & $5.22 \mathrm{E}-07$ \\
\hline & $\mathrm{R}^{2}$ & 0.934 \\
\hline \multirow{3}{*}{$\begin{array}{l}\text { Harkin- } \\
\text { Jura }\end{array}$} & $\mathrm{B}$ & -0.267 \\
\hline & A & 0.0086 \\
\hline & $\mathrm{R}^{2}$ & 0.6029 \\
\hline \multirow{3}{*}{ Temkin } & $\beta_{\mathrm{T}}$ & 0.28 \\
\hline & $\mathrm{K}_{\mathrm{T}}$ & 17 \\
\hline & $\mathrm{R}^{2}$ & 0.898 \\
\hline \multirow{3}{*}{ Elovich } & $\mathrm{q}_{\mathrm{m}}$ & 0.95 \\
\hline & $\mathrm{K}_{\mathrm{e}}$ & 0.6 \\
\hline & $\mathrm{R}^{2}$ & 0.961 \\
\hline \multirow{3}{*}{$\begin{array}{l}\text { Redlich- } \\
\text { Peterson }\end{array}$} & $\mathrm{B}$ & 0.166 \\
\hline & $\mathrm{A}$ & 0.15 \\
\hline & $\mathrm{R}^{2}$ & 0.968 \\
\hline \multirow{3}{*}{ Toth } & $\mathrm{n}$ & 0.6719 \\
\hline & $\mathrm{K}_{\mathrm{L}}$ & 12 \\
\hline & $\mathrm{R}^{2}$ & 0.62953 \\
\hline \multirow{3}{*}{ Josens } & $\mathrm{H}$ & 0.25 \\
\hline & $\mathrm{F}$ & 0.179 \\
\hline & $\mathrm{R}^{2}$ & 0.961 \\
\hline
\end{tabular}

3.2. Adsorption kinetics and mechanism studies.

Figure 12 shows the time-quantity relationship for $\mathrm{CO}_{2}$ adsorbed. The rate of adsorption reduces as the cycle lengthens until equilibrium is reached.

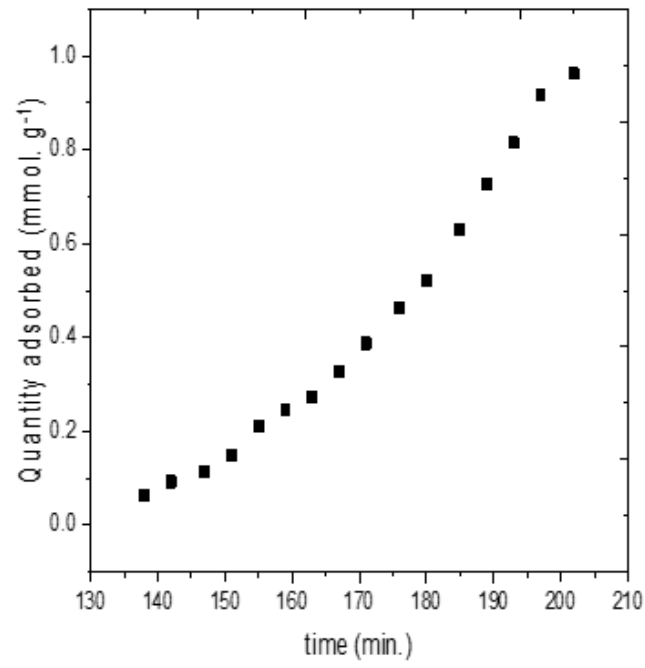

Figure 12. At 273 degrees Celsius, $\mathrm{CO}_{2}$ adsorption vs. time.

The $\mathrm{CO}_{2}$ absorption rate is determined via adsorption kinetics analysis, and this rate precisely controls $\mathrm{CO}_{2}$ uptake vs. time at the solid-gas interface. The degree of $\mathrm{CO}_{2}$ removal by adsorption was first high, then steadily declined until it reached an equilibrium, above which 
the rate of removal rapidly increased. It is the most adsorbent. After computing the ideal adsorption, the time of balance was calculated to be 202 minutes.

\subsubsection{The pseudo-first-order}

According to the kinetic model equations, pseudo-first-order kinetic models were used to fit the experimental data and track the adsorption kinetics of tested PMNs (Figure 13).

Pseudo-first-order devolped by Lagergren[49,50].

$$
\log \left(\mathrm{q}_{\mathrm{e}}-\mathrm{q}_{\mathrm{t}}\right)=\log \mathrm{q}_{\mathrm{e}}-\left(\mathrm{K}_{1} /(2.303)\right) \mathrm{t}
$$

A straight line with a $-K_{1}$ slope and intercept $\ln$ qe emerges from the plot of $\ln \left(\mathrm{q}_{\mathrm{e}}-\mathrm{q}_{\mathrm{t}}\right)$ vs. t.

\subsubsection{The pseudo-second-order.}

A pseudo second order kinetic model[51] was used to connect the experimental data:

$$
\mathrm{t} / \mathrm{q}_{\mathrm{t}}=1 /\left(\mathrm{K}_{2} \mathrm{qe}^{2}\right)+\mathrm{t} / \mathrm{q}_{\mathrm{e}}
$$

The values of $\mathrm{K}_{2}$ and qe for the quantity of $\mathrm{CO}_{2}$ adsorbed were calculated using the slope and linear plot intercept of $\mathrm{t} / \mathrm{q}_{\mathrm{t}} v s$. t. (Figure 13).

\subsubsection{Webber (intraparticle diffusion)}

Weber assumed an empirical connection with four parameters over a wide range of adsorption systems, providing an excellent interpretation of the data pattern[52].

$$
\mathrm{q}_{\mathrm{t}}=\mathrm{Ki} \mathrm{t}^{(1 / 2)}+\mathrm{X}
$$

The $\mathrm{K}_{\text {dif }}$ and $\mathrm{C}$ parameters were calculated using the $\mathrm{q}_{\mathrm{t}} v s . \mathrm{t}^{1 / 2}$ linear plot.

Only the early stages of adsorption (initial steep climb) are considered relevant for the external barrier to mass transfer around the particles. The second linear segment, which is controlled by intraparticle diffusion, covers the common adsorption processes. If the plots do not pass through the origin, it means that pore diffusion isn't the sole rate-limiting step; additional kinetic models, all of which can operate simultaneously, can also limit the adsorption rate [53]. (Figure 13).

\subsubsection{Elovich.}

The equations that characterize this model are based on a kinetic principle that asserts that the number of adsorption sites increases exponentially as adsorption occurs, implying multilayer adsorption [41].

$$
\mathrm{q}_{\mathrm{t}}=1 / \beta \ln (\alpha \beta)+1 / \beta \ln \mathrm{t}
$$

A line plot of $\mathrm{q}_{\mathrm{t}} v s$. $\ln _{\mathrm{t}}$ on the slope and intercept, respectively, yielded the constants and (Figure 13).

The Elovich equation demonstrated that the active sites of the adsorbent are heterogeneous, resulting in chemisorption activation energies that vary. As the amount of $\mathrm{CO}_{2}$ increased, the constant (which is linked to the rate of chemisorption) increased as well, whereas the constant $\beta$ (connected to the surface coverage) dropped.

Table 2 When the experimental $\mathrm{CO}_{2}$ adsorption data are set to $273 \mathrm{k}$ and air pressure Kinetic models are employed, the values for their corresponding parameters are shown. 

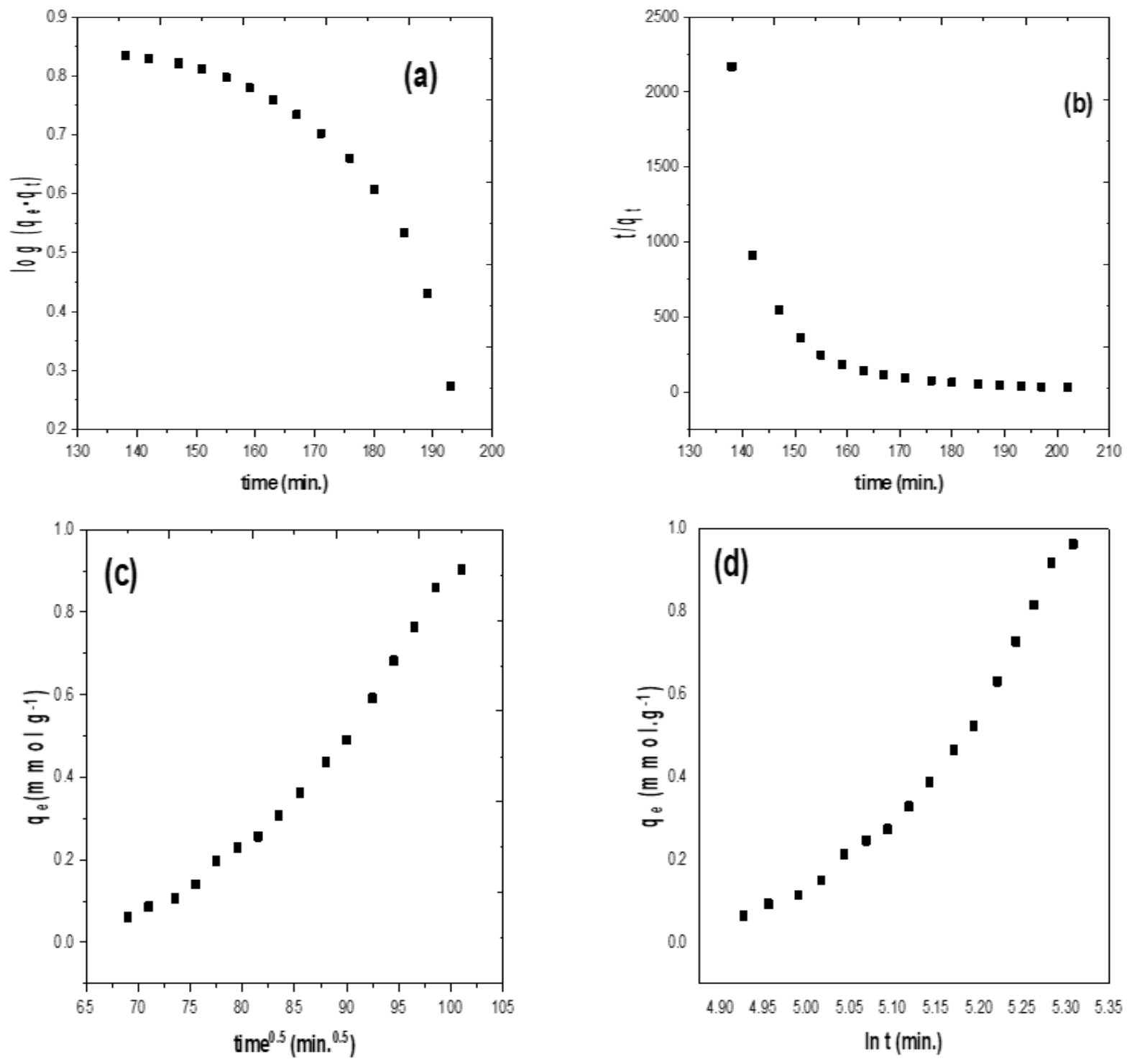

Figure 13. Application of kinetic models to data collected from $\mathrm{CO}_{2}$ adsorption on the surface of PMNs yielded the following results: (a)pseudo-first-order; (b) pseudo-second-order; (c) Webber intra-particle diffusion; (d) Elovich model.

Table 2. Kinetic models.

\begin{tabular}{c|c|c} 
Models & Parameter & PMNs \\
\hline $\begin{array}{c}\text { Pseudo-First-order } \\
\text { kinetic }\end{array}$ & $K_{l}\left(\mathrm{~min}^{-1}\right)$ & 0.0086 \\
\cline { 2 - 3 } $\begin{array}{c}\text { Pseudo-second-order } \\
\text { kinetic }\end{array}$ & $\mathrm{R}^{2}$ & 0.8124 \\
\cline { 2 - 3 } $\begin{array}{c}K_{2}\left(\mathrm{~g} \mathrm{mg}^{-1} \mathrm{~min}^{-1}\right) \\
\text { Intraparticle } \\
\text { diffusion }\end{array}$ & $\mathrm{R}^{2}$ & 0.1004 \\
\cline { 2 - 3 } & $\mathrm{K}_{\mathrm{i}}\left(\mathrm{mgg}^{-1} \mathrm{~min}^{1 / 2}\right)$ & 0.438 \\
\cline { 2 - 3 } & $\mathrm{X}\left(\mathrm{mgg}^{-1}\right)$ & 0.0274 \\
\hline \multirow{2}{*}{ Elovich } & $\mathrm{R}^{2}$ & 0.963 \\
\cline { 2 - 3 } & $\alpha\left(\mathrm{g} / \mathrm{mg}^{2}\right)$ & 0.4166 \\
\cline { 2 - 3 } & $\left.\alpha \mathrm{mgg}^{-1} \cdot \mathrm{min}^{-1}\right)$ & $5.84 \mathrm{E}-06$ \\
\hline
\end{tabular}

The order in which the kinetic models were fitted to the experimental data is as follows: Intra-particle diffusion $>$ Elovich $>$ pseudo first order $>$ modified pseudo first order $>$ pseudo second order.

The intraparticle diffusion model provided the best fit for the experimental results.

Three steps are thought to be involved in the adsorption process: 
External surface adsorption, intraparticle diffusion, and the final balance define the eventual balance. Figure 13(c) shows two linear stages corresponding to intraparticle diffusion and the equilibrium plateau, while external diffusion is absent due to the $\mathrm{CO}_{2}$ adsorption process in the aerogels. The adsorption rate was fairly high because intra-particle diffusion occurred in the mesopores in theory. At this moment, $\mathrm{CO}_{2}$ and PMNs had reached an equilibrium plateau, and the adsorption rate had slowed.

The second-best fit to the experimental data was supplied by the Elovich model, showing that the surface adsorption sites were energetically heterogeneous. Because the other models studied had a lower correlation coefficient, they couldn't explain the adsorption processes as well. On the other hand, the pseudo-second-order model exhibited the worst adjustment, indicating that chemisorption was not involved and that the interactions between the adsorbate and the adsorbent were solely physical[54].

The $\alpha$ and $\beta$ constants obtained by applying the Elovich model have units of $\left(\mathrm{mgg}^{-1} \cdot \mathrm{min}^{-}\right.$ $\left.{ }^{1}\right)$ and $(\mathrm{g} / \mathrm{mg})$, respectively. The values of $\alpha$ determine the initial adsorption speed. Their values were 5.84E-06 mgg- $\mathrm{min}^{-1}$ ) for the materials PMNs indicating that the initial adsorption rate is related to the capacity of $\mathrm{CO}_{2}$ adsorption under these conditions.

The value of the constant $\beta$ presents the smallest value in the material. $0.42 \mathrm{~g} / \mathrm{mg}$; As a result, because it possessed the most mesopores, this material had the largest capacity for $\mathrm{CO}_{2}$ adsorption [18].

Another study discovered that the pseudo-first-order and pseudo-second-order models did not best fit data from $\mathrm{CO}_{2}$ adsorption kinetics at solid surfaces.

\subsection{Comparison with other adsorbents.}

Tables 3 examine and contrast the optimum $\mathrm{CO} 2$ adsorption power of PMNs as an adsorbent with that of the other adsorbents previously mentioned. This implies that both $\mathrm{CO} 2$ and PMNs have a high adsorption capacity. Tables 3 examine and contrast the optimum $\mathrm{CO} 2$ adsorption power of PMNs as an adsorbent with that of the other adsorbents previously mentioned. This implies that both $\mathrm{CO}_{2}$ and PMNs have a high adsorption capacity.

Table 3. Comparison of $\mathrm{CO}_{2}$ adsorption by PMNs vs. other adsorbents.

\begin{tabular}{l|l|l} 
Adsorbent & $\mathbf{q m}\left(\mathbf{m m o l g}^{-\mathbf{1}}\right)$ & Reference \\
\hline $\begin{array}{l}\text { Mesoporous } \mathrm{TiO}_{2} \text { bead } \\
\text { bentonite }\end{array}$ & 0.41 & {$[55]$} \\
\hline Porous organic polymer & 0.95 & {$[56]$} \\
\hline Bentonite & 0.14 & {$[57]$} \\
\hline Acid treated bentonite & 0.59 & {$[58]$} \\
\hline MOF-5 & 0.86 & {$[59]$} \\
\hline ZIF-8 & 30 & {$[60]$} \\
\hline SBA-15 & 0.48 & {$[60]$} \\
\hline APS-MCM-48 & 0.79 & {$[61]$} \\
\hline S3 & 0.73 & {$[8]$} \\
\hline PMNs & 0.96 & This work
\end{tabular}

\section{Conclusions}

A porous magnetite $\mathrm{Fe}_{3} \mathrm{O}_{4}$ nanospheres (PMNs) sample was tested for $\mathrm{CO}_{2}$ adsorption/desorption at $273 \mathrm{~K}$ and 1 bar of pressure. The adsorption capacity of PMNs is 0.96 $\mathrm{mmol} / \mathrm{g}$. The $\mathrm{CO}_{2}$ adsorption isotherm of PMNs matches type IV of the IUPAC adsorption isotherm classification, which most likely indicates adsorption limited to a few molecular 
layers (micropores and mesoporous). The adsorption and desorption isotherms for PMNs samples contain hysteresis, according to the results of the experiments. During $\mathrm{CO}_{2}$ adsorption and desorption on PMNs, the hysteresis loop was classified as $\mathrm{H}_{3}$. Adsorption isotherm models were found to fit experimental data, implying that adsorption takes place on a heterogeneous surface with different affinities of adsorption sites. Stronger binding sites are occupied first when a material's surface properties are predicted to be heterogeneous, and binding strength declines as the degree of occupation increases. The intraparticle diffusion hypothesis best fits the experimental results. This model was used to assess the rate data from the studies. Both the intraparticle diffusion and equilibrium plateau models yielded values that were consistent with the experimental results. According to the kinetic investigation, the Elovich model provides the second-best match to the obtained data, resulting in an energy distribution throughout the surface of the materials throughout the $\mathrm{CO}_{2}$ adsorption process.

\section{Funding}

This research received no external funding.

\section{Acknowledgments}

The authors declare no acknowledgments.

\section{Conflicts of Interest}

The authors declare no conflict of interest

\section{References}

1. Lee, D.; Jin, Y.; Jung, N.; Lee, J.; Lee, J.; Jeong, Y.S.; Jeon, S. Gravimetric analysis of the adsorption and desorption of $\mathrm{CO} 2$ on amine-functionalized mesoporous silica mounted on a microcantilever array. $J$ Environmental science technology 2011, 45, 5704-5709.

2. Lee, S.Y.; Park, S.J. Determination of the optimal pore size for improved $\mathrm{CO}_{2}$ adsorption in activated carbon fibers. Journal of colloid interface science 2013, 389, 230-235.

3. Hassan, N.; El-Sonbati, A.; El-Desouky, M. Synthesis, characterization, molecular docking and DNA binding studies of $\mathrm{Cu}$ (II), Ni (II), Zn (II) and Mn (II) complexes. Journal of Molecular Liquids 2017, 242, 293-307, https://dx.doi.org/10.1016/j.molliq.2017.07.019.

4. Fávaro, W.J.; de Souza, J.G.; Matsumoto, M.Y.; Durán, M.; Bockelmann, P.K.; Dias, Q.C.; Durán, N. Associating Graphene Oxide Derivatives to Treat Non-Muscle Invasive Bladder Cancer (NMIBC). Biointerface Research in Applied Chemistry 2021, 12, 196-210, https://doi.org/10.33263/BRIAC121.196210.

5. Zhao, H.Y.; Cao, Y.; Lineberry, Q.; Pan, W.P. Evaluation of $\mathrm{CO}_{2}$ adsorption capacity of solid sorbents. Journal of thermal analysis calorimetry 2011, 106, 199-205.

6. Russell, B.A.; Migone, A.D. Low temperature adsorption study of $\mathrm{CO}_{2}$ in ZIF-8. J Microporous Mesoporous Materials 2017, 246, 178-185.

7. Yadav, J.N.; Singh, N.P. Fluid Flow Characterization of Single-Strand Tundish with Flow Modifiers through Physical Water Model (PWM) and CFD Simulation. Biointerface Research in Applied Chemistry 2021, 12, 211-221, https://doi.org/10.33263/BRIAC121.211221.

8. Abunowara, M.; Bustam, M.A.; Sufian, S.; Eldemerdash, U. Description of carbon dioxide adsorption and desorption onto Malaysian coals under subcritical condition. J Procedia engineering 2016, 148, 600-608.

9. Ozdemir, E. Modeling of coal bed methane (CBM) production and $\mathrm{CO}_{2}$ sequestration in coal seams. $J$ International Journal of Coal Geology 2009, 77, 145-152.

10. He, J.; Shi, Y.; Ahn, S.; Kang, J.W.; Lee, C.H. Adsorption and desorption of $\mathrm{CO}_{2}$ on Korean coal under subcritical to supercritical conditions. J The Journal of Physical Chemistry B 2010, 114, 4854-4861. 
11. M.G. El-Desouky, A. Shahat, A.A. El-Bindary, M.A. El-Bindary, Description, Kinetic and Equilibrium Studies of the Adsorption of Carbon Dioxide in Mesoporous Iron Oxide Nanospheres, Biointerface Resarch in Applied Chemistry, 12 (2021) 1022-1038.

12. White, C.M.; Smith, D.H.; Jones, K.L.; Goodman, A.L.; Jikich, S.A.; LaCount, R.B.; DuBose, S.B.; Ozdemir, E.; Morsi, B.I.; Schroeder, K.T. Sequestration of carbon dioxide in coal with enhanced coalbed methane recovery a review. J Energy Fuels 2005, 19, 659-724.

13. El-Desouky, M.G.; Abd El-Wahab, M.; El-Bindary, A.A. Interpretations and DFT Calculations for Polypropylene/Cupper Oxide Nanosphere. Biointerface Research in Applied Chemistry 2021, 12, 1134-1147, https://doi.org/10.33263/BRIAC121.11341147.

14. Battistutta, E.; Van Hemert, P.; Lutynski, M.; Bruining, H.; Wolf, K.H. Swelling and sorption experiments on methane, nitrogen and carbon dioxide on dry Selar Cornish coal. J International Journal of Coal Geology 2010, 84, 39-48.

15. El-Desouky, M.; El-Bindary, M.; El-Bindary, A. Effective adsorptive removal of anionic dyes from aqueous solution. Vietnam Journal of Chemistry 2021, 59, 341-361, http://DOI://10.1002/vjch.202000184.

16. Mohamed, G.; Hassan, N.; Shahat, A.; El-Didamony, A.; Ashraf, A. Synthesis and Characterization of Porous Magnetite Nanosphere Iron Oxide as a Novel Adsorbent of Anionic Dyes Removal from Aqueous Solution.

Biointerface Research in Applied Chemistry 2021, 11, 13377-13401, https://doi.org/10.33263/BRIAC115.1337713401.

17. Busch, A.; Gensterblum, Y.; Krooss, B.M. Methane and CO2 sorption and desorption measurements on dry Argonne premium coals: pure components and mixtures. J International Journal of Coal Geology 2003, 55, 205-224.

18. Hassan, N.; Shahat, A.; El-Daidamony, A.; El-Desouky, M.; El-Bindary, A. Synthesis and characterization of $\mathrm{ZnO}$ nanoparticles via zeolitic imidazolate framework-8 and its application for removal of dyes. Journal of Molecular Structure 2020, 128029, https://doi.org/10.1016/j.molstruc.2020.128029.

19. Santhi, T.; Manonmani, S.; Smitha, T. Removal of methyl red from aqueous solution by activated carbon prepared from the Annona squmosa seed by adsorption. J Chemical engineering research bulletin 2010, 14, 11-18.

20. Jaya, A.; Wahyudin, E.; Djabir, Y.Y.; Roska, T.P.; Arfiansyah, R.; Dirpan, A.; Nainu, F. Phenotypical Effect of Phosphodiesterase 5 (PDE5) Inhibitor on Behavioral Activities of Fruit Fly Drosophila melanogaster. Biointerface Research in Applied Chemistry 2021, 12, 222-229, https://doi.org/10.33263/BRIAC121.222229.

21. Ruthven, D.M. Principles of adsorption and adsorption processes; John Wiley \& Sons: 1984.

22. Ayawei, N.; Ebelegi, A.N.; Wankasi, D. Modelling and interpretation of adsorption isotherms. Journal of Chemistry 2017, 2017.

23. Fouda, A.E.A.S.; Motaal, S.M.A.; Ahmed, A.S.; Sallam, H.B.; Ezzat, A.; El-Hossiany, A. Corrosion Protection of Carbon Steel in 2M HCl Using Aizoon canariense Extract. Biointerface Research in Applied Chemistry 2021, 12, https://doi.org/10.33263/BRIAC121.230243.

24. Elmorsi, T.M. Equilibrium isotherms and kinetic studies of removal of methylene blue dye by adsorption onto miswak leaves as a natural adsorbent. Journal of Environmental Protection 2011, 2, 817.

25. Günay, A.; Arslankaya, E.; Tosun, I.s. Lead removal from aqueous solution by natural and pretreated clinoptilolite: adsorption equilibrium and kinetics. Journal of hazardous material 2007, 146, 362-371.

26. Dąbrowski, A. Adsorption-from theory to practice. J Advances in colloid interface science 2001, 93, 135224.

27. Harismah, K.; Fazeli, F.; Zandi, H. Barbituric Acid Tautomers: DFT Computations of Keto-Enol Conversions, Frontier Molecular Orbitals and Quadrupole Coupling Constants. Biointerface Research in Applied Chemistry 2021, 12, 244-252, https://doi.org/10.33263/BRIAC121.244252.

28. Achour, Y.; El Kassimi, A.; Nadir, I.; Yazid, H.; Hafid, A.; Khouili, M.; El Himri, M.; Laamari, M.R.; El Haddad, M. Simultaneous Removal of Binary Mixture of Cationic Dyes onto Bombax Buonopozense Bark: Plackett-Burman and Central Composite Design. Biointerface Research in Applied Chemistry 2021, 12, 326338, https://doi.org/10.33263/BRIAC121.326338.

29. Ayawei, N.; Ekubo, A.; Wankasi, D.; Dikio, E. Adsorption of congo red by Ni/Al-CO3: Equilibrium, thermodynamic and kinetic studies. J Oriental Journal of Chemistry 2015, 31, 1307-1318.

30. Boparai, H.K.; Joseph, M.; O'Carroll, D.M. Kinetics and thermodynamics of cadmium ion removal by adsorption onto nano zerovalent iron particles. Journal of hazardous materials 2011, 186, 458-465. 
31. Pattnaik, S.S.; Nanda, B.; Dalai, B.; Nanda, B.B. Effect of the Temperature and Solvents on the Solvolysis of Barium Bromide in Aqueous-Organic Solutions: Volumetric and Viscometric Study. Biointerface Research in Applied Chemistry 2021, 12, 339-350, https://doi.org/10.33263/BRIAC121.339350.

32. Travis, C.; Etnier, E.L. A survey of sorption relationships for reactive solutes in soil. Journal of Environmental Quality 1981, 10, 8-17.

33. Celebi, O.; Üzüm, Ç.; Shahwan, T.; Erten, H.N. A radiotracer study of the adsorption behavior of aqueous Ba2+ ions on nanoparticles of zero-valent iron. Journal of Hazardous Materials 2007, 148, 761-767.

34. Ashraf, A.; El-Desouky, M.G.; El-Afify, M.A. Thermal and Spectroscopic Studies of Some Prepared Metal Complexes and Investigation of their Potential Anticancer and Antiviral Drug Activity against SARS-CoV2 by Molecular Docking Simulation. Biointerface Research in Applied Chemistry 2021, 12, 1053-1075, https://doi.org/10.33263/BRIAC121.10531075.

35. Santhi, T.; Manonmani, S.; Smitha, T. Removal of malachite green from aqueous solution by activated carbon prepared from the epicarp of Ricinus communis by adsorption. Journal of hazardous materials 2010, 179, 178-186.

36. Hassan, N.; Shahat, A.; El-Didamony, A.; El-Desouky, M.; El-Bindary, A. Mesoporous iron oxide nano spheres for capturing organic dyes from water sources. Journal of Molecular Structure 2020, 1217, 128361, https://doi.org/10.1016/j.molstruc.2020.128361.

37. Vyshnava, S.S.; Pandluru, G.; Kumar, K.D.; Prasad, S. A Computational Approach for Protein-Protein Interactions of Bacterial Surface Layer Protein with Human Erb3 and $\alpha$ IIB- $\beta 3$ Receptors. Biointerface Research in Applied Chemistry 2021, 12, 420-430, https://doi.org/10.33263/BRIAC121.420430.

38. Foo, K.Y.; Hameed, B.H. Insights into the modeling of adsorption isotherm systems. J Chemical engineering journal 2010, 156, 2-10.

39. Shahbeig, H.; Bagheri, N.; Ghorbanian, S.A.; Hallajisani, A.; Poorkarimi, S. A new adsorption isotherm model of aqueous solutions on granular activated carbon. J World Journal of ModellingSimulation 2013, 9 , 243-254.

40. Ringot, D.; Lerzy, B.; Chaplain, K.; Bonhoure, J.-P.; Auclair, E.; Larondelle, Y. In vitro biosorption of ochratoxin A on the yeast industry by-products: Comparison of isotherm models. J Bioresource technology 2007, 98, 1812-1821.

41. Gubernak, M.; Zapala, W.; Kaczmarski, K. Analysis of amylbenzene adsorption equilibria on an RP-18e chromatographic column. J Acta Chromatographica 2003, 13.

42. Hamdaoui, O.; Naffrechoux, E. Modeling of adsorption isotherms of phenol and chlorophenols onto granular activated carbon: Part I. Two-parameter models and equations allowing determination of thermodynamic parameters. J Journal of Hazardous materials 2007, 147, 381-394.

43. Reddy, B.V.N.; Reddy, B.V.S.; Kumar, N.S.; Naidu, K.C.B. Materials for Conversion of CO2. Biointerface Research in Applied Chemistry 2021, 12, 486-497, https://doi.org/10.33263/BRIAC121.486497.

44. M.G. El-Desouky, M.A.Khalil, A.A. El-Bindary, M.A. El-Bindary, Biological, Biochemicaland Thermochemical Techniques for Biofuel production : an Updated Review, Biointerface Resarch in Applied Chemistry, 12 (2022) 3034-3054.

45. Brouers, F. On the optimal use of isotherm models for the characterization of biosorption of lead onto algae. Journal of Molecular Liquids 2015, 212, 46-51.

46. Chan, L.; Cheung, W.; Allen, S.; McKay, G. Error analysis of adsorption isotherm models for acid dyes onto bamboo derived activated carbon. J Chinese Journal of Chemical Engineering 2012, 20, 535-542.

47. A. Ashraf, M.G. El-Desouky, M.A. El-Afify, Thermal and Spectroscopic Studies of Some Prepared Metal Complexes and Investigation of their Potential Anticancer and Antiviral Drug Activity against SARS-CoV2 by Molecular Docking Simulation, Biointerface Resarch in Applied Chemistry, 12 (2021) 1053-1075.

48. Dilekoglu, M.F. Use of Genetic Algorithm Optimization Technique in the Adsorption of Phenol on Banana and Grapefruit Peels. Journal of the Chemical Society of Pakistan 2016, 38.

49. Ho, Y.S.; McKay, G. Sorption of dye from aqueous solution by peat. J. Chemical Engineering Journal 1998, 70, 115-124.

50. Lagergren, S.K. About the theory of so-called adsorption of soluble substances. Journal Sven. Vetenskapsakad. Handingarl 1898, 24, 1-39.

51. Ho, Y.S.; McKay, G. Sorption of dye from aqueous solution by peat. Jornal Chemical engineering journal 1998, 70, 115-124. 
52. Vijayaraghavan, K. Biosorption of lanthanide (praseodymium) using Ulva lactuca: Mechanistic study and application of two, three, four and five parameter isotherm models. Journal of Environment Biotechnology Research 2015, 1, 10-17.

53. M. El-Bindary, M. El-Desouky, A. El-Bindary, Adsorption of industrial dye from aqueous solutions onto thermally treated green adsorbent: A complete batch system evaluation, Journal of Molecular Liquids, (2021) 117082.

54. Hassan, N.; Shahat, A.; El-Didamony, A.; El-Desouky, M.; El-Bindary, A. Equilibrium, Kinetic and Thermodynamic studies of adsorption of cationic dyes from aqueous solution using ZIF-8. J Moroccan Journal of Chemistry 2020, 8, 8-3, 2627-2637, https://doi.org/10.48317/IMIST.PRSM/morjchemv8i3.21127.

55. Aquino, C.C.; Richner, G.; Chee Kimling, M.; Chen, D.; Puxty, G.; Feron, P.H.; Caruso, R.A. Aminefunctionalized titania-based porous structures for carbon dioxide postcombustion capture. The Journal of Physical Chemistry C 2013, 117, 9747-9757.

56. Guillerm, V.; Weseliński, Ł.J.; Alkordi, M.; Mohideen, M.I.H.; Belmabkhout, Y.; Cairns, A.J.; Eddaoudi, M. Porous organic polymers with anchored aldehydes: a new platform for post-synthetic amine functionalization en route for enhanced CO 2 adsorption properties. J Chemical Communications 2014, 50, 1937-1940.

57. Chen, C.; Park, D.-W.; Ahn, W.-S. Surface modification of a low cost bentonite for post-combustion $\mathrm{CO}_{2}$ capture. J Applied surface science 2013, 283, 699-704.

58. Bereket, G.; Arog, A.Z.; Özel, M.Z. Removal of Pb (II), Cd (II), Cu (II), and Zn (II) from aqueous solutions by adsorption on bentonite. Journal of Collö̈d interface science 1997, 187, 338-343.

59. Lu, C.-M.; Liu, J.; Xiao, K.; Harris, A.T. Microwave enhanced synthesis of MOF-5 and its $\mathrm{CO}_{2}$ capture ability at moderate temperatures across multiple capture and release cycles. J Chemical Engineering Journal 2010, $156,465-470$.

60. Chen, C.; Kim, J.; Yang, D.-A.; Ahn, W.-S. Carbon dioxide adsorption over zeolite-like metal organic frameworks (ZMOFs) having a sod topology: Structure and ion-exchange effect. J Applied surface science 2011, 168, 1134-1139.

61. Kim, S.; Ida, J.; Guliants, V.V.; Lin, Y. Tailoring pore properties of MCM-48 silica for selective adsorption of CO2. J The Journal of Physical Chemistry B 2005, 109, 6287-6293. 